\title{
Larval Predation on Different Instars in Blowfly Populations
}

\author{
Lucas Del Bianco Faria ${ }^{1}$, Wesley Augusto Conde Godoy ${ }^{1 *}$ and Sérgio Furtado dos Reis ${ }^{2}$ \\ ${ }^{I}$ Departamento de Parasitologia; Instituto de Biociências; Universidade Estadual Paulista - UNESP; \\ wgodoy@ibb.unesp.br; 18618-000; Botucatu - SP - Brazil. ${ }^{2}$ Departamento de Parasitologia; Instituto de Biologia; \\ Universidade Estadual de Campinas - UNICAMP; Campinas - SP - Brazil
}

\begin{abstract}
During its larval stage, Chrysomya albiceps (Diptera: Calliphoridae) is a facultative predator on other blowflies. In this study, we evaluated the predation by third instar larvae of C. albiceps on first, second and third instar larvae of Chrysomya megacephala and Cochliomyia macellaria in no-choice experiments in order to compare the vulnerability of larval instars to predation. With first and second instar prey the highest predation rate by $C$. albiceps was on C. megacephala. For third instar prey, the highest predation rate was on C. macellaria. With second instar prey, there was complete predation on C. megacephala within 90 min, whereas in C. macellaria only $55 \%$ of the larvae were eaten by 90 min. For third instar prey most predation on C. macellaria (80\%) occurred within $90 \mathrm{~min}$, whereas in C. megacephala only 35\% of the larvae were eaten by 90 min. Chrysomya albiceps changes the predatory behavior on its preys depending on which instar and species it will consume.
\end{abstract}

Key words: Chrysomya albiceps, blowflies, larval predation, optimal foraging

\section{INTRODUCTION}

Blowflies usually feed on carcasses which, because of their ephemeral nature, provide only limited resources for several species (Kneidel, 1984a, b). The abundance of flies and the high number of species in carcasses results in depletion of this food supply and flies cannot persist for more than one generation on this substrate (Putman, 1977; Hanski, 1987; Ives, 1988). Then, carrion size limits the availability of food, which in turn influences the life history of each species (Denno and Cothran, 1975). When resources are limited, there may be competition, cannibalism or predation among species (Ullyett, 1950; Polis, 1981; Faria et al., 1999). Individuals of different instars generally coexist in carrion, and this increases the chance of encounters between predators and prey or between weak and strong competitors (Taylor, 1984).

Among blowflies, two species, Chrysomya rufifacies and $C$. albiceps, are facultative predators on the other dipteran larvae (Fuller, 1934; Coe, 1978; Gagné, 1981; Erzinçlioglu and Whitcombe, 1983). As with other blowfly species $C$. ruffifacies and $C$. albiceps preferentially consume carcass until resources become limiting. However, when food is scarce, both species may change their behaviour to become facultative predators (Ullyett, 1950; Faria et al., 1999). As predators, these species show interspecific preferences (Wells and Kurahashi, 1997; Faria et al., 1999), which may change according to the prey species available (Faria and Godoy, 2001), i.e. they are generalist predators.

Generalist predators may choose their prey based on the energetic value and cost associated with

*Author for correspondence 
capture and indigestion (Charnov, 1976). Optimal foraging theory (Stephens and Krebs, 1986) assumes that predators use different prey to maximize their energetic gain. It has been usually assumed that the energetic value and the encounter rate are functions of prey size and, therefore, that predators prefer large prey, which offer more nutritional advantages (Charnov, 1976). In addition, prey detection, and the mobility and rapidity of the predator following prey contact are constraints that may strongly influence the success of prey capture (Malcolm, 1992).

The preference of different species has been related to factors such as sex (Selander, 1966), age (Sandling and Willig, 1993), size (Zerba and Collins, 1992), spatial location (Murdoch et al., 1975) and chance encounters (Sherratt and Mcdougall, 1995). Several authors have suggested that size is an important factor in determining vulnerability of prey (Barbeau and Scheibling, 1994; Ofuya, 1995; Suchman and Sullivan, 2000). Age and size structure in predator and prey populations can greatly influence predation (Taylor, 1984). The two best known agedependent aspects of predation are the development of hunting skills and the relative vulnerability of young and old prey (Taylor, 1984). All of these factors can influence the predator handling time, which varies according to the prey used (Gotelli, 1995).

Old World flies of the genus Chrysomya were introduced into the Americas in the mid 1970s (Guimarães et al., 1978, 1979; Baumgartner and Greenberg, 1984; Laurence, 1986). These flies have since become widespread and abundant in the Neotropical region, with the main species being $C$. albiceps, C. megacephala and C. putoria (Guimarães et al., 1978, 1979; Prado and Guimarães, 1982). The introduction of Chrysomya species has affected the native fauna composition to the extent that the native calliphorid $C$. macellaria has since become rare or extinct in some regions (Guimarães et al., 1979; Prado and Guimarães, 1982; Baumgartner and Greenberg, 1984; Paraluppi and Castellon, 1994).

Competition and predation between Chrysomya spp. and $C$. macellaria have had a strong negative effect on C. macellaria (Wells and Greenberg, 1992a, b, c; Faria et al., 1999; Reis et al., 1999; Von Zuben et al., 2000). In location where $C$. albiceps and $C$. putoria were abundant the native species was reduced by almost $90 \%$ (Baumgartner and Greenberg, 1984). Chrysomya albiceps is a facultative predator during its larval stage, and experimental evidences indicate that $C$. albiceps has a stronger impact on the third larval instar of C. macellaria than on other species (Wells and Greenberg, 1992a; Wells and Kurahashi, 1997; Faria et al., 1999).

Although there is some information on behaviour related to prey capture and consumption (Wells and Greenberg, 1992a; Wells and Kurahashi, 1997; Faria et al., 1999; Faria and Godoy, 2001), no systematic study has examined the relationship between predatory behaviour and prey size or species among blowflies. In this work, we examined the influence of prey size and prey species on predation by the facultative predator C. albiceps under laboratory conditions.

\section{MATERIALS AND METHODS}

Laboratory populations of $C$. albiceps, $C$. megacephala and $C$. macellaria were obtained from specimens collected on the campus of the Universidade Estadual Paulista. Adult flies were maintained at $25 \pm 1^{0} \mathrm{C}$ in cages $(30 \mathrm{~cm} \mathrm{x} 30 \mathrm{~cm} \mathrm{x}$ $30 \mathrm{~cm}$ ), covered with nylon and were fed water and sugar ad libitum. Eggs were obtained by providing females with fresh beef liver. Hatched larvae were reared on an excess of ground beef until the third instar in the case of $C$. albiceps (predator), and until the first, second and third instars in the case of $C$. megacephala (prey) and $C$. macellaria (prey), at which point they were used in the experiments described below. The larval instars were identified based on accepted morphological characters used to separate the various development stages of blowflies (Prins, 1982; Greenberg and Szyska, 1984; Erzinçlioglu, 1990; Tantawi and Greenberg, 1993; Queiroz et al., 1997).

Predation rates were evaluated in no-choice situations in which first, second or third instars $C$. megacephala or $C$. macellaria were placed together with third instar $C$. albiceps in a Petri dish (30 $\mathrm{mm}$ diameter). One specimen of each species per pair $(C$. albiceps x $C$. megacephala or $C$. albiceps x C. macellaria) was used for each larval stage. Forty Petri dishes were prepared for each combination and were placed on an illuminated laboratory bench at room temperature. The larvae were observed continuously for $3 \mathrm{~h}$ and the instances of predation on $C$. megacephala and $C$. 
macellaria larvae by $C$. albiceps were recorded every $30 \mathrm{~min}$. Predatory behaviour was considered successful when $C$. albiceps surrounded and mortally pierced its prey which struggled violently in response.

The number of killed and surviving larvae of each species in each setting was analysed statistically using the $\chi^{2}$ test for the homogeneity of rates. The rates of predation on each species were analysed further by considering only the cases of predation, and were compared between species using the $\chi^{2}$ test. The predation rate distribution over time was also compared between species and within instars using the $\chi^{2}$ statistics. In all comparisons the Yates correlation for continuity of the $\chi^{2}$ statistics was applied (Zar, 1999).

\section{RESULTS}

Tables 1-3 show the predation rates for the total number of vials $(\%)$ and the cumulative predation rate $(\%)$ for consecutive time intervals in the different combinations. For first instar prey, the highest predation rate by $C$. albiceps $(20 \%)$ was on C. megacephala, compared to $12.5 \%$ on $C$. macellaria (Table 1). However, the predation rates were statistically homogeneous $\left(\chi^{2}=0.36 ;\right.$ d.f. $=$ $2 ; p>0.05)$. The distribution of predation rates over time was also statistically homogeneous $\left(\chi^{2}=\right.$ $0.31 ; d . f .=4 ; p>0.05)$. Thus, the predation rates by $C$. albiceps and their distribution over time were the same for both species (Table 1).

With second instar prey (Table 2), the highest predation rate by C. albiceps $(100 \%)$, was again on C. megacephala, compared to $92.5 \%$ on $C$. macellaria; these predation rates were statistically homogeneous $\left(\chi^{2}=1.41 ;\right.$ d.f. $\left.=2 ; p>0.05\right)$. There was complete predation on $C$. megacephala within 90 min, whereas in C. macellaria only $55 \%$ of the larvae were eaten by $90 \mathrm{~min}$. As a result, the distribution of predation by $C$. albiceps over time was significantly different $\left(\chi^{2}=18.94 ; d . f .=4 ; p\right.$ $<0.05)$. Although the predation rates were the same, the time spent attacking $C$. megacephala was less than for C. macellaria (Table 2).

For third instar prey, the highest predation rate (95\%) was on C. macellaria, compared to $72.5 \%$ on $C$. megacephala (Table 3). However, the predation rates were statistically homogenous $\left(\chi^{2}\right.$ $=5.88 ;$ d.f. $=2 ; p>0.05)$. Most predation on C. macellaria (80\%) occurred within $90 \mathrm{~min}$, whereas in C. megacephala only $35 \%$ of the larvae were eaten by $90 \mathrm{~min}$. The distribution of the predation rates over time were therefore significantly different $\left(\chi^{2}=14.1 ;\right.$ d.f. $=4 ; p<$ $0.05)$. Although the predation rates by $C$. albiceps were the same for the two prey, the predation rates on prey species changed according to the instars, and the distribution over time for predation on $C$. macellaria was shorter than for C. megacephala (Table 3).

There was a significant difference in the predation rates among the three instars of $C$. megacephala and the number of survival preys $\left(\chi^{2}=53.69 ;\right.$ d.f. $=3 ; p<0.05)$ (Fig. 1a). The highest predation rate by $C$. albiceps was on the second instar with all larvae being killed. The predation rate on the third instar was $72.5 \%$ and on the first instar, $20 \%$. There was also a significant difference in the predation rates $\left(\chi^{2}=10.54 ;\right.$ d.f. $\left.=2 ; p<0.05\right)$, and in the distribution of these rates over time for the last two instars $\left(\chi^{2}=33.76 ;\right.$ d.f. $\left.=4 ; p<0.05\right)$.

The predation rates on the three instars of $C$. macellaria and the preys that were not killed were significantly different $\left(\chi^{2}=74.44 ;\right.$ d.f. $=3 ; p<$ $0.05)$. The highest predation rate by $C$. albiceps occurred on the third instar, with $95 \%$ of the larvae killed. On the second instar, the rate was $92.5 \%$ and on first instar, $12.5 \%$. However, between the second and third instars, there was statistical homogeneity for the predation rates $\left(\chi^{2}=0 ; d . f .=\right.$ $2 ; p>0.05)$, and their distribution $\left(\chi^{2}=4.54 ; d . f\right.$. $=4 ; p>0.05)$ (Fig. 1b).

\section{DISCUSSION}

Our results suggest that the preference for prey depended to some extent on the instar. Chrysomya albiceps showed different predatory behaviour depending on the species and instars. Different predation rates between $C$. rufifacies larval instars and $C$. macellaria were described by Wells and Greenberg (1992a), with the third instar being most frequently attacked. Chysomya rufifacies showed predatory behaviour only in the third instar. However, C. macellaria was attacked by $C$. rufifacies in both the second and third instars (Wells and Greenberg, 1992a). Many factors influence prey selection. 
Table 1 - Predation rates by Chrysomya albiceps on larvae of first instar of Chrysomya megacephala and Cochliomyia macellaria.

\begin{tabular}{crrrr}
\hline \multirow{2}{*}{ Time (min) } & \multicolumn{2}{c}{ C. megacephala } & \multicolumn{2}{c}{ C. macellaria } \\
\cline { 2 - 5 } & PR & CR & PR & CR \\
\hline 30 & 5 & 5 & 0 & 0 \\
60 & 5 & 10 & 0 & 0 \\
90 & 0 & 10 & 7,5 & 7,5 \\
120 & 5 & 15 & 0 & 7,5 \\
150 & 2,5 & 17,5 & 0 & 7,5 \\
180 & 2,5 & 20 & 5 & 12,5 \\
& & & & 12,5 \\
\hline
\end{tabular}

$\mathrm{PR}=$ Predation rates for $n=40$

$\mathrm{CR}=$ Cumulative rate

Table 2 - Predation rates by Chrysomya albiceps on larvae of second instar of Chrysomya megacephala and Cochliomyia macellaria.

\begin{tabular}{crrrr}
\hline \multirow{2}{*}{ Time $(\mathbf{m i n})$} & \multicolumn{2}{c}{ C. megacephala } & \multicolumn{2}{c}{ C. macellaria } \\
\cline { 2 - 5 } & PR & CR & PR & CR \\
\hline 30 & 35 & 35 & 25 & 25 \\
60 & 47,5 & 82,5 & 22,5 & 47,5 \\
90 & 17,5 & 100 & 7,5 & 55 \\
120 & - & - & 17,5 & 72,5 \\
150 & - & - & 10 & 82,5 \\
180 & - & - & 10 & 92,5 \\
Total & 100 & 100 & 92,5 & 92,5 \\
\hline
\end{tabular}

$\mathrm{PR}=$ Predation rates for $n=40$

$\mathrm{CR}=$ Cumulative rate

Table 3. Predation rates by Chrysomya albiceps on larvae of third instar of Chrysomya megacephala and Cochliomyia macellaria.

\begin{tabular}{ccccc}
\hline \multirow{2}{*}{ Time (min) } & \multicolumn{2}{c}{ C. megacephala } & \multicolumn{2}{c}{ C. macellaria } \\
\cline { 2 - 5 } & PR & CR & PR & CR \\
\hline 30 & 10 & 10 & 22,5 & 22,5 \\
60 & 12,5 & 22,5 & 42,5 & 65 \\
90 & 12,5 & 35 & 15 & 80 \\
120 & 20 & 55 & 10 & 90 \\
150 & 15 & 70 & 5 & 95 \\
180 & 2,5 & 72,5 & 0,0 & 95 \\
& & & & 95 \\
\hline
\end{tabular}

$\mathrm{PR}=$ Predation rates for $\mathrm{n}=40$

$\mathrm{CR}=$ Cumulative rate

The prey size is important in terms of optimum foraging (Zerba and Collins, 1992), and may contribute to prey vulnerability (Barbeu and Scheibling, 1994; Ofuya, 1995; Suchman and Sullivan, 2000). Chance encounters between prey and predator (Sherratt and McDougall, 1995) and prey and predator age (Sandling and Willig, 1993) are also important factors in the dynamics of predation.

Optimal foraging theory assumes that predators use different prey types to maximize their rate of energetic gain (Stephens and Krebs, 1986). Even if 
the energetic value of the prey is a key factor in prey selection, foraging predators usually face several problems that may influence their net energy gain and, consequently, prey profitability (Krebs and McCleery, 1984). Studies of preypredator and host-parasitoid dynamics have shown that the capture rate may decrease with increasing prey size because of better defense responses in larger prey or a greater ability to escape (Pastorok, 1981; Chau and Mackauer, 1997). According to optimal foraging theory, predators are expected to use large prey in order to maximize energy return (Schoener, 1969). On the other hand, consuming smaller prey may be advantageous if large preys are costly in terms of the risks of injury. Better defense responses by the prey may increase the risk of predator death as well as the time needed to handle prey (Pastorok, 1981; Sabelis, 1992). As a result profitable larger prey may be less.

(a)

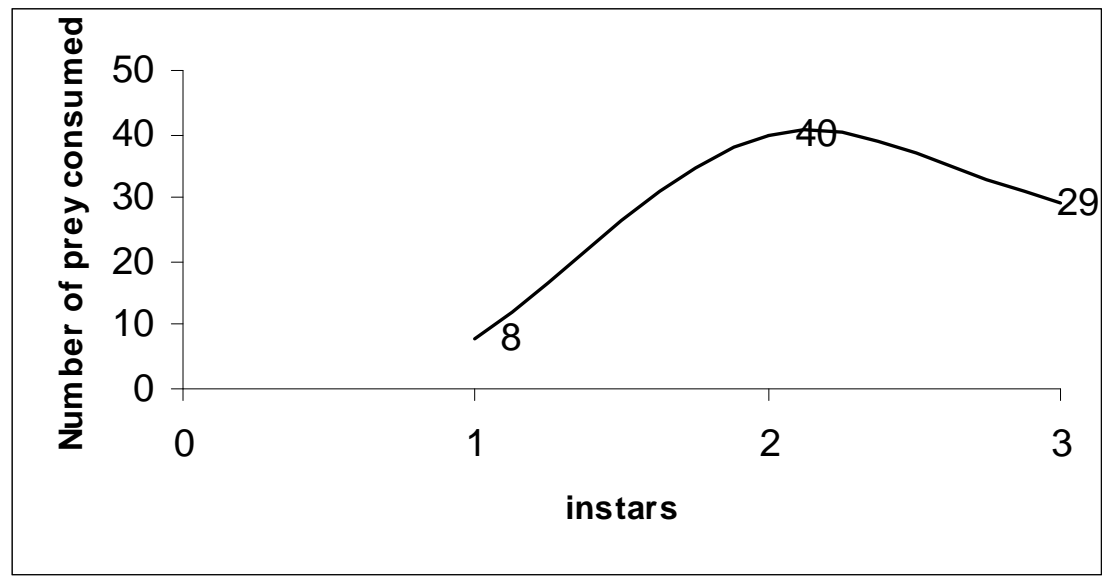

(b)

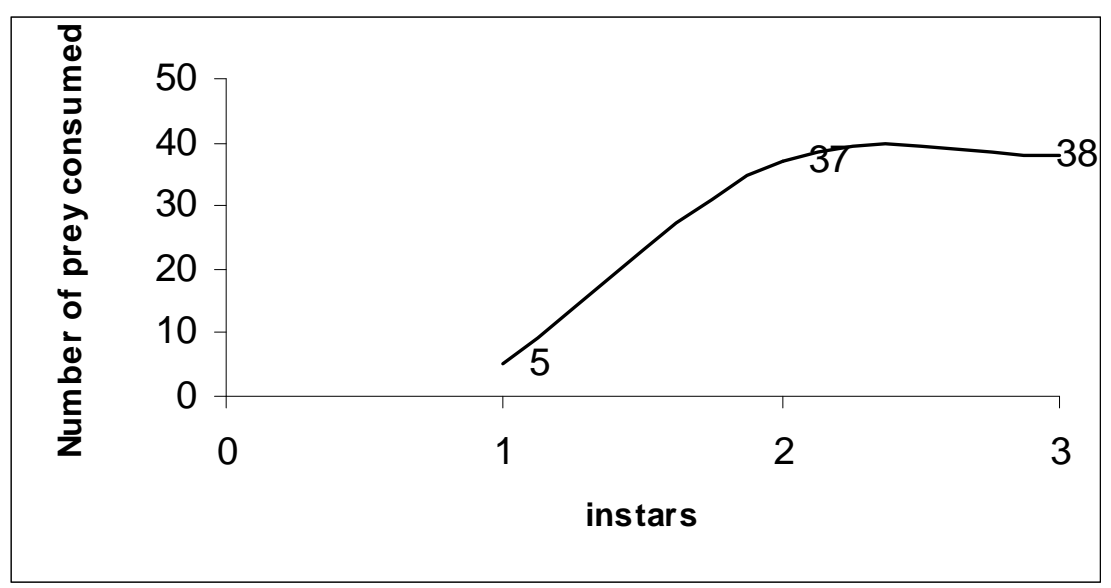

Figure 1 - Consumption of blowfly larvae by Chrysomya albiceps: (a) Consumption of Chrysomya megacephala larvae by Chrysomya albiceps according to instar; (b) Consumption of Cochliomyia macellaria larvae by Chrysomya albiceps according to instar.

Hence, even if the nature of the costs associated with the use of small and large prey is different, both could result in a lower net energy gain than with intermediate sized prey (Roger et al., 2000). Elner and Hughes (1978) studied the predation of shelfish by crabs and noted that crabs preferred intermediate preys to increase profitability. Similar behaviour was observed by Roger et al. (2000), with predatory coccinellids attacking more lepdopteran larvae of intermediate size. 
This kind of behaviour could be described as a convex curve to the axis, where the highest peak of predation is placed in mid point, when compared to smaller or larger point (Pastorok, 1981).

In our study, the first instar prey was smaller than the predator and this have made their detection by the predator difficult. Such a benefit could serve as a type of refuge (Suchman and Sullivan, 2000). On the other hand, third instar prey were the same size as the predator and had been difficult to attack. However, they were the easiest to detect as a consequence of chance encounter, and their ability to escape (meant that the predator had to spend more time handling them) (Faria, 2001). Prey of intermediate size was easier to find than first instar larvae and had a weaker defense response than third instar larvae. This behaviour occurred mainly with $C$. megacephala larvae as prey.

Significant negative correlations between prey size and consumption rate occurred in spiders (Henaut et al., 2001). However the defensive behaviour of prey may also influence the consumption rate of predators (HoughGoldstein, 1996; Henaut et al., 2001). This behaviour could explain the shift in prey preference among blowfly instars. In the second instar, $C$. megacephala was more vulnerable to predation by $C$. albiceps than $C$. macellaria. Chrysomya albiceps fed more voraciously on $C$. megacephala than $C$. macellaria, and $C$. megacephala showed less agility in escaping from $C$. albiceps. In addition to prey vulnerability, other factors such as palatability and pheromones could explain the rapid capture of $C$. megacephala second instar larvae.

The force required by the predator to bite and the work involved in biting are additional factors probably associated with prey size (Andrews and Bertram, 1997). A combination of mechanical measurements in vitro with behaviour analysis could provide an estimate of the total mechanical labor per feeding event. Such an analysis could indicate whether the total labor increases with prey size and whether the difference between prey types is far less than predicted by variations in the structural properties of the prey (Andrews and Bertram, 1997).

Faria et al. (1999) analysed the predation rates of $C$. albiceps on third instar larvae of $C$. megacephala, $C$. putoria and $C$. macellaria. Chrysomya albiceps attacked more C. macellaria larvae than C. megacephala and C. putoria larvae in choice experiments. In the absence of $C$. macellaria larvae, $C$. albiceps attacked more $C$. putoria larvae than $C$. megacephala larvae (Faria and Godoy, 2001). These results clearly showed that $C$. albiceps chose alternative prey when the preferred prey was not present. We concluded that there were significant differences among the three species of prey (C. megacephala, C. putoria and C. macellaria) since $C$. albiceps showed a graded preference for them. Second instar larvae of $C$. megacephala were consumed more quickly than C. macellaria larvae. Our initial expectation was for the opposite to occur since $C$. macellaria had been displaced by $C$. albiceps, $C$. putoria, $C$. rufifacies and $C$. megacephala following introduction of Chrysomya about 25 years ago to the Americas (Prado and Guimarães, 1982; Wells and Greenberg, 1992a, b, c).

To conclude, $C$. albiceps seemed to change its predatory behaviour as a function of prey development stage and species. In carcasses, the presence of different blowfly species in different life stages is common. Larval predation is probably a frequent interaction in carcasses since the food is generally scarce and number of prey and predator present is frequently high. Chrysomya albiceps plays an important role in necrophagous dipteran community since it behaves as an intraguild predator (Polis et al., 1989).

\section{ACKNOWLEDGEMENTS}

This work was supported by grants from Fundação de Amparo à Pesquisa do Estado de São Paulo (No. 01/11235-1). LDBF, WACG and SFR thank research fellowships from Fundação Coordenação de Aperfeiçoamento de Pessoal de Nível Superior and Conselho Nacional de Desenvolvimento Científico e Tecnológico. The authors also thank Dr. Stephen Hyslop (Department of Pharmacology, UNICAMP) for reviewing the English of the manuscript.

\section{RESUMO}

Chrysomya albiceps (Diptera: Calliphoridae) é uma predadora facultativa sobre outras moscasvarejeiras, durante o terceiro instar larval. Nesse estudo, nos investigamos a taxa de predação de $C$. albiceps sobre larvas de primeiro, segundo e 
terceiro instar de $C$. megacephala e $C$. macellaria comparando a vulnerabilidade dos instares larvais frente à predadora. Para as presas de primeiro e segundo instar, C. albiceps apresentou maior taxa de predação sobre $C$. megacephala. Já sobre larvas de terceiro instar a predadora consumiu mais $C$. macellaria. O comportamento de $C$. albiceps sobre as duas espécies de presas sugere uma mudança na estratégia de forrageio da predadora e essa mudança pode ter influencia sobre a comunidade de dípteros necrófagos.

\section{REFERENCES}

Andrews, C. and Bertram, J. E. A. (1997), Mechanical work as a determinant of prey-handling behavior in the Tokay gecko (Gekko gecko). Phys. Zoo., 70, 193-201.

Barbeau, M. A. and Scheibling, R. E. (1994), Behavioral mechanisms of prey size selection by sea stars (Asterias vulgaris (Verril)) and crabs (Cancer irroratus (Say)) preying on juvenile sea scallops (Placopecten magellanicus (Gmelin)). J. Exp. Mar. Bio. Eco., 180, 103-136.

Baumgartner, D. L. and Greenberg, B. (1984), The genus Chrysomya (Diptera: Calliphoridae) in the New World. J. Med. Entomol., 21, 105-113.

Charnov, E. L. (1976), Optimal foraging, the marginal value theorem. Theo. Pop. Bio., 9, 129-136.

Chau, A. and Mckauer, M. (1997), Dropping of pea aphids from feeding site: a consequence of parasitism by the wasp, Nonoctonus paulensis. Ent. Exp. App., 83, 247-252.

Coe, R L. (1978), The decomposition of elephant carcases in the Tsavo (East) National, Kenya. J. Ar. Env., 1, 71-86.

Denno, R. F. and Cothran, W. R. (1975), Niche relationships in a guild of necrophagous flies. Ann. Ent. Soc. Am., 68, 741-754.

Elner, R. W. and Hughes, R. N. (1978), Energy maximization in the diet of the shore crab, Carcinus maenas. J. Anim. Ecol., 47, 103-116.

Erzinçlioglu, Y. Z. (1990), The larvae of two closelyrelated blowfly species of the genus Chrysomya (Diptera, Calliphoridae). Ent. Fenn., 3, 151-153.

Erzinçlioglu, Y. Z. and Whitcombe, R. P. (1983), Chrysomya albiceps (Wiedemann) (Dipt., Calliphoridae) in dung and causing myiasis in Oman. Ent. Mon. Mag., 119, 51-52.

Faria, L. D. B. (2001), Predação larval e resposta funcional em populações experimentais de Chrysomya albiceps (Diptera: Calliphoridae). Dissertação (Mestrado) - Programa de Pós-graduação em Ciências Biológicas (Zoologia), Instituto de Biociências de Botucatu, UNESP.
Faria, L. D. B. and Godoy, W. A. C. (2001), Prey choice by facultative predator larvae of Chrysomya albiceps (Diptera: Calliphoridae). Mem. Inst. Osw. Cruz, 96, 875-878.

Faria, L. D. B.; Orsi, L.; Trinca, L. A. and Godoy, W. A. C. (1999), Larval predation by Chrysomya albiceps on Cochliomyia macellaria, Chrysomya megacephala and Chrysomya putoria. Ent. Exp. App., 90, 149-155.

Fuller, M. E. (1934), The insect inhabitants of carrrion, a study in animal ecology. Bull. Counc. Sci. Ind. Res., 82, 5-62.

Gagné, R. J. (1981), Chrysomya spp., Old World blowflies (Diptera, Calliphoridae), recently established in the Americas. Bull. Ent. Soc. Am., 27, 21-22.

Godoy, W. A. C.; Von Zuben, C. J. and Ribeiro, O. B. (1993), Population dynamics of Chrysomya putoria (Wied.) (Dipt., Calliphoridae). J. App. Ent., 116, 163-169.

Gotelli, N. J. (1995), A primer of ecology. Sinauer Associates, Sunderland MA.

Greenberg, B. and Szyska, M. L. (1984), Immature stages and biology of fifteen species of peruvian Calliphoridae (Diptera). Ann. Ent. Soc. Am., 77, 488-517.

Guimarães, J. H.; Prado, A. P. and Linhares, A. X. (1978), Three newly introduced blowfly species in Southern Brazil (Diptera: Calliphoridae). Rev. Bras. Ent., 22, 53-60.

Guimarães, J. H.; Prado, A. P. and Buralli, G. M. (1979), Dispersal and distribution of three newly introduced species of Chrysomya Robineau-Desvoidy in Brazil (Diptera, Calliphoridae). Rev. Bras. Ent., 23, 245-255.

Hanski, I. (1987), Carrion fly community dynamics: Patchiness, seasonality and coexistence. Ecol. Ent., 12, 257-26.

Henaut, Y.; Pablo, J.; Ibarra-Nunez, G. and Williams, T. (2001), Retention, capture and consumption of experimental prey by orb-web weaving spiders in coffee plantations of Southern Mexico. Ent. Exp. App., 98, 1-8.

HoughGoldstein, J.; Cox, J. and Armstrong, A. (1996), Podisus maculiventris (Hemiptera: Pentatomidae) predation on ladybird beetles (Coleoptera: Coccinellidae). Flor. Ent., 79, 64-68.

Ives, A. R. (1988), Aggregation and the coexistence of competitors. Ann. Zoo. Fenn., 25, 75-88.

Kneidel, K. A. (1984a), Competition and disturbance in communities of carrion breeding diptera. J. Anim. Ecol., 53, 849-865.

(1984b), The influence of carcass taxon and size on species composition of carrion-breeding Diptera. Am. Mid. Nat., 111, 57-63.

Krebs, J. R. and McCleery, R. H. (1984), Optimization in behavioural ecology. In: Krebs, J. R. and Davies, N. B. (Eds.). Behavioral Ecology, an Evolutionary Approach. Oxford : Blackwell Scientific. pp. 91-121. 
Laurence, B. R. (1986), Old World Blowflies in the New World. Para. Today, 2, 77-79.

Malcolm, S. B. (1992), Prey defense and predator foraging. In: Crawley, M. J. (Ed.). Natural Enemies. Oxford : Blackwell Scientific Publications. pp. 458-475.

Murdoch, W. W.; Avery, S. and Smyth, M. E. B. (1975), Switching in predatory fish. Ecol., 56, 1094-1105.

Ofuya, T. I. (1995), Studies on the capability of Cheilomenes lunata (Fabricius) (Coleoptera, Coccinellidae) to prey on the Cowpea aphid, Aphis craccivora (Koch) (Homoptera, Aphididae) in Nigeria. Agric. Ecos. Env. 52, 35-38.

Paraluppi, N.D.; Castellon, E. G. (1994), Calliphoridae (Diptera) em Manaus: I. Levantamento taxonômico e sazonalidade. Rev. Bras. Ent., 38, 661-668.

Pastorok, R. A. (1981), Prey vulnerability and size selection by Chaoborus larvae. Ecol., 62, 1311-1324.

Polis, G. A. (1981), The evolution of dynamics of intraspecific predation. Ann. Rev. Ecol. Sys., 12, 125-251.

Polis, G. A.; Myers, C. A. and Holt, R. D. (1989), The ecology and evolution of intraguild predation: Potential competitors that eat each other. Ann. Rev. Ecol. Sys., 20, 297-330.

Prado, A. P. and Guimarães, J. H. (1982), Estado atual de dispersão e distribuição do gênero Chrysomya Robineau-Desvoidy na região Neotropical (Diptera: Calliphoridae). Rev. Bras. Ent., 26, 225-231.

Prins, A. J. (1982), Morphological and biological notes on six African blow-flies (Diptera, Calliphoridae) and this immature stages. Ann. South Afr. Mus., 90, 201-217.

Putman, R. J. (1977), Dynamics of the blowfly, Calliphora erythrocephala, within carrion. J. Anim. Ecol., 46, 853-866.

Queiroz, M. M. C.; Mello, R. P. and Lima, M. M. (1997), Morphological aspects of the larval instars of Chrysomya albiceps (Diptera, Calliphoridae) reared in the laboratory. Mem. Inst. Osw. Cruz, 92, 187-196.

Reis, S. F.; Von Zuben, C. J. and Godoy, W. A. C. (1999), Larval aggregation for food in experimental population of Chrysomya putoria (Wied.) and Cochliomyia macellaria (F.) (Dipt. Calliphoridae). J. App. Ent., 123, 485-489.

Roger, C.; Coderre, D. and Boivin, G. (2000), Differential prey utilization by generalist predator Coleomegilla maculata lengi according to prey size and species. Ent. Exp. App., 94, 3-13.

Sabelis, M. W. (1992), Predatory arthropods. In: Crawley, M. J. (Ed.). Natural Enemies. Oxford : Blackwell Scientific Publications. pp. 225-264.

Sandling, E. A. and Willing, M. R. (1993), Effects of age, Sex, prior experience and intraespecific food variation on diet composition of a tropical folivore (Phasmatodea, Phasmatidae). Env. Ent., 22, 625-633.

Schoener, T. W. (1969), Models of optimal size for solitary predators. Am. Nat., 103, 277-313.
Selander, R. K. (1966), Sexual dimorphism and differential niche utilization in birds. Condor, 68, 113-151.

Sherratt, T. N. and Macdougall, A. D. (1995), Some population consequences of variation in preference among individual predators. Biol. J. Linn. Soc., 55, 93-107.

Stephens, D. W. and Krebs, J. R. (1986), Foraging Theory. Princeton : Princeton University Press.

Suchman, C. L. and Sullivan, B. K. (2000), Effect of prey size on vulnerability of copepods to predation by the scyphomedusae Aurelia aurita and Cyanea sp. J. Plank. Res., 22, 2289-2306.

Tantawi, T. I. and B. Greenberg (1993), Chrysomya albiceps and C. rufifacies (Diptera: Calliphoridae). Cont. Ong. Tax. Prob., 30, 646-648.

Taylor, R. J. (1984), Predation. New York : Chapman and Hall.

Ullyett, G. C. (1950), Competition for food and allied phenomena in sheep-blowfly populations. Phil. Trans. R. Soc. Lon., B234, 77-174.

Von Zuben, C. J. V.; Stangenhaus, G. and Godoy, W. A. C. (2000), Competição larval em Chrysomya megacephala (F) (Diptera: Calliphoridae): efeitos de diferentes níveis de agregação larval sobre estimativas de peso, fecundidade e investimento reprodutivo. Rev. Bras. Biol., 60, 195-203.

Wells, J. D. and Greenberg, B. (1992a), Rates of predation by Chrysomya rufifacies (Macquart) on Cochliomyia macellaria (Fabr.) (Diptera: Calliphoridae) in the laboratory: Effect of predator and prey development. Pan-Pacific Ent., 68, 12-14. (1992b), Laboratory interaction between introduced Chrysomya rufifacies and native Cochliomyia macellaria (Diptera: Calliphoridae). Env. Ent., 21, 640-645.

(1992c), Interaction between Chrysomya rufifacies and Cochliomyia macellaria (Diptera: Calliphoridae): the possible consequences of an invasion. Bull. Ent. Res., 82, 133-137.

Wells, J. D. and Kurahashi, H. (1997), Chrysomya megacephala (Fabr.) is more resistant to attack by Chrysiomya rufifacies (Marcquart) in laboratory arena than is Cochliomyia macellaria (Fabr.) (Diptera: Calliphoridae). Pan-Pacific Ent., 73, 16-20.

Zar J. H. (1999), Biostatistical analysis. $4^{\text {nd }}$ ed. N. J. : Prentice Hall.

Zerba, K. E. and Collins, J. P. (1992), Spatial heterogeneity and individual variation in the diet of an aquatic top predator. Ecol., 73, 268-279.

Received: February 19, 2003; Revised: January 27, 2004; Accepted: July 09, 2004. 